\title{
Como o passado pode nos ajudar a prever o futuro?
}

\author{
How can the past help us to predict the future?
}

\author{
German E. Berrios \\ Professor BA (Oxford), DPhilSci (Oxford), MA (Cambridge), MD, FRCPsych, FBPsS, FMedSci. \\ Doutor honoris causa em Medicina (Heidelberg, San Marcos). Professor, Epistemologia da Psiquiatria, \\ University of Cambridge, Cambridge, Reino Unido. Consultor em Neuropsiquiatria. Coordenador, Serviços \\ Neuropsiquiátricos.
}

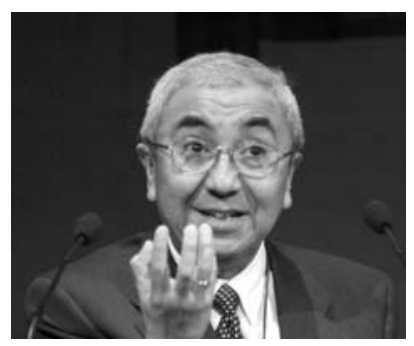

Fico agradecido aos editores da Revista de Psiquiatria do Rio Grande do Sul por me solicitarem a escrever este breve editorial sobre o título acima, o qual suponho que pretende saber se, em psiquiatria, o conhecimento histórico pode ter capacidade preditiva. A resposta é complexa e depende, em grande parte, da maneira como definimos psiquiatria, história e capacidade preditiva.

Por psiquiatria, entendo o conjunto de narrativas desenvolvidas (principalmente por sociedades ocidentais) para configurar, explicar e lidar com fenômenos comportamentais, os quais, com base em critérios sociais mais do que neurobiológicos, foram definidos como "desvios". Atualmente, tais narrativas são predominantemente médicas, mas a aliança entre medicina e loucura também é histórica por natureza e pode muito bem ser dissolvida no futuro. Essa dissolução seria determinada por fatores sociais, e não por fatores científicos.

História refere-se ao conjunto de narrativas desenvolvidas para capturar e reconfigurar agrupamentos contemporâneos de idéias, emoções e ações humanas na medida em que elas ocorrem em determinadas coordenadas espaço-temporais. No caso da história da psiquiatria, tais coordenadas serão determinadas pelo que é definido (em um certo período) como a relação entre sociedade e loucura.

Capacidade preditiva refere-se ao poder de especificar no presente os formatos e interações comportamentais que ocorrerão no futuro. Previsões são mais difíceis (porém mais significativas) em modelos historiográficos lineares do que em não-lineares. Por exemplo, de uma perspectiva viconiana (circular), a repetição de certas maneiras de ver as coisas pode ser prevista com facilidade, mas essa ação terá pouco significado.

A história da psiquiatria pode ser concebida como uma disciplina autônoma ou utilitária. De acordo com a primeira, seu objetivo é entender e explicar como e porque a linguagem, construção e tratamento da "doença mental” se desenvolveram através dos séculos. De acordo com a segunda, a história da psiquiatria é simplesmente uma "fonte de erros", um "tesouro sem dono", "um adorno cosmético" ou um "instrumento preditivo" (ou todos juntos). Embora essas duas perspectivas sejam muitas vezes confundidas, elas precisam ser diferenciadas, uma vez que a história não tem e nem se deve esperar que tenha qualquer obrigação utilitária.

O fato de que (no sentido braudeliano) a história da psiquiatria parece exibir processos de longa, média e curta duração pode, em algumas ocasiões, induzir em todos nós uma ilusão oracular, ou seja, o sentimento profundo de que podemos "ver" padrões e repetições na evolução da psiquiatria, e que estes podem nos permitir prever o futuro. Por exemplo, é tentador imaginar que períodos de biologismo psiquiátrico à outrance sejam seguidos de rebeliões hermenêuticas (como no caso da neuropsiquiatria do final do século XIX e do freudianismo do início do século XX). Isso nos levaria a prever que a tendência atual de "naturalizar" todos os fenômenos psiquiátricos seria seguida de um período governado por uma abordagem semântica à doença mental mais balanceada.

As pressuposições escondidas que inspiram esse "pensamento desejante" (wishful thinking) devem ser explicitadas. A principal delas é que a psiquiatria é um ramo autônomo da ciência aplicada que evolui de acordo com suas leis internas de lógica e com sua própria pesquisa e evidência científica. Esta visão é, certamente, sem sentido. A psiquiatria é uma disciplina parasitária cujo caminho sinuoso não é determinado por leis evolucionárias internas, mas pelos caprichos do mercado, isto é, por fatores econômicos, sociais e políticos. Mesmo sua aliança atual com a medicina 
poderia cessar rapidamente se o mercado descobrisse que há maneiras mais baratas e vendáveis de tratar a loucura.

É certo que a natureza econômica dessa decisão nunca será explicitada, pois logo filósofos e historiadores da corte se mobilizarão para tramar narrativas justificatórias que farão com que a decisão pareça ser tomada com base em ideais supremos e evidências duramente adquiridas. Um bom exemplo é a atual ameaça à "continuidade de assistência", um dos princípios sagrados em torno do qual a psiquiatria britânica se organizou desde 1948 (ou seja, o desejo de que o mesmo psiquiatra cuide de um paciente e de sua família). Por ser menos dispendioso ter psiquiatras tratando somente pacientes hospitalizados ou ambulatoriais, alguns Consórcios Britânicos de Saúde Mental decidiram agora abolir o princípio da continuidade. Isso foi encoberto por uma narrativa justificatória, a saber: é melhor para um paciente ser atendido por vários psiquiatras, já que isso reduz a probabilidade de erro diagnóstico!

É evidente que isso não faz sentido, pois a psiquiatria tem um número limitado de “doenças", um número limitado de "tratamentos" e é uma disciplina "segura”, no sentido de que é difícil cometer "erros” diagnósticos, os quais raramente podem pôr em risco a vida do paciente (como pode ocorrer em outras especialidades médicas). Seja como for, muito mais importante do que o perigo teórico de "erro diagnóstico" é o conhecimento profundo que, por toda sua vida, o psiquiatra acumulará de seu paciente, doença, família e contexto social.

É verdade que, por vezes, a história da psiquiatria pode revelar idéias, tratamentos ou abordagens que foram negligenciadas ou porque a tecnologia de um determinado período não era compatível, ou porque o status social do psiquiatra que os postulou era baixo demais, ou porque os mandarins da disciplina investiram sua reputação e dinheiro em outras coisas. Essas idéias, tratamentos ou abordagens podem, em princípio, ser resgatados e, neste sentido, diz-se que a história pode ser um “tesouro sem dono”. Porém, esta não é uma situação comum.

Em resumo, cada período histórico tem suas próprias narrativas dominantes. Estas atingem o poder porque geram ganho financeiro para todos os interessados (exceto para os pobres pacientes). Se há uma lição a ser aprendida da história, é que esta situação estrutural tende a se repetir, no sentido de que, em cada período histórico, o establishment apontará uma elite em especial para configurar e tratar a loucura. Infelizmente, quem essas elites serão e quais narrativas elas tramarão não pode ser previsto. Tudo que pode ser previsto é que a disposição geral se repetirá e que nenhuma elite durará para sempre.

Esta transitoriedade deveria ser uma fonte de esperança para aqueles que sentem que os atuais fundamentalismos biológicos não estão causando bem algum a nossos pacientes e que essa visão exagerada deve ser balanceada pela criação de um espaço semântico onde possamos atender àqueles que precisam de ajuda.

Há causas e razões para a aflição mental. Causas no sentido de que transtornos cerebrais podem sobrepujar sua psicologia. Razões no sentido de que a vida das pessoas pode se tornar insuportável, porque elas são confrontadas com situações extremas diante das quais sua organização emocional e semântica se torna insuficiente ou impotente. $\mathrm{O}$ fato de que, neste último caso, o sofrimento das pessoas também tenha uma “representação cerebral” é completamente irrelevante para seu tratamento. Para serem ajudados, esses pacientes devem ser atendidos em seu próprio espaço psicológico. Isso é algo que talvez não possamos aprender da história, mas que parece suficientemente verdadeiro para nós que cuidamos deles. 